\title{
Osteogenic potential of punica granatum through matrix mineralization, cell cycle progression and runx2 gene expression in primary rat osteoblasts
}

Sahabjada Siddiqui and Mohammad Arshad*

\begin{abstract}
Background: Osteoporosis is one of the prevalent diseases in ageing populations. Due to side effects of many chemotherapeutic agents, there is always a need to search for herbal products to treat the disorder. Punica granatum $(\mathrm{PG})$ represent a potent fruit-bearing medicinal herb which exerted valuable anti-osteoporotic activities. The present study was carried out to validate the in vitro osteogenic effects of the PG seed extract in primary calvarial osteoblast cultures harvested from neonatal rats.

Methods: The ethanolic extract of PG was subjected to evaluate cell proliferation, regeneration, mineralization and formation of collagen matrix using MTT, alkaline phosphatase, Alizarin Red-S staining and Sirius Red dye, respectively. Cell cycle progression and osteogenic gene Runx2 expression were carried out by flow cytometry and real time PCR, respectively.

Results: Exposure of different concentrations (10-100 $\mu \mathrm{g} / \mathrm{ml})$ of the extract on osteoblastic cells showed characteristic morphological changes and increment in cell number. A significant growth in cell proliferation, ALP activity, collagen contents and matrix mineralization of osteoblasts in a dose dependent manner $(p<0.05)$, suggested that PG has a stimulatory effect on osteoblastic bone formation or potential activity against osteoporosis. In addition, PG extract also enhanced DNA content in S phase of cell cycle and Runx2 gene expression level in osteoblasts.

Conclusion: The data clearly indicated that PG promoting bone cell proliferation and differentiation in primary osteoblasts might be due to elevating the osteogenic gene Runx2 expression. The present study provides an evidence for PG could be a promising herbal medicinal candidate that able to develop drugs for osteoporosis.
\end{abstract}

Keywords: Cell cycle, Osteoblast, Osteogenesis, Punica granatum, Runx2

\section{Introduction}

Osteoporosis is a metabolic bone disorders that afflicts about 200 million people worldwide. It is mainly prevalent in women (approximately 80\%) and also older men [1]. The bone remodeling process is the alternative of this severe concern, and it's dependable for repair of damage or formation and resorption of bones to maintain the integrity of the skeleton. However, any abnormalities in remodeling that lead to fracture in the bones and osteoporosis.

Recently, several conventional and antiresorptive drugs are used to reduce fracture risk in osteoporosis including hormone replacement therapy (HRT), bisphosphonates,

\footnotetext{
* Correspondence: molendolab@gmail.com

Molecular Endocrinology Laboratory, Department of Zoology, University of Lucknow, Lucknow 226007, India
}

(c) 2014 Siddiqui and Arshad; licensee BioMed Central Ltd. This is an Open Access article distributed under the terms of the Creative Commons Attribution License (http://creativecommons.org/licenses/by/4.0), which permits unrestricted use, distribution, and reproduction in any medium, provided the original work is properly credited. The Creative Commons Public Domain Dedication waiver (http://creativecommons.org/publicdomain/zero/1.0/) applies to the data made available in this article, unless otherwise stated. selective estrogen receptor modulators (SERMs) and calcitonin [2]. However, these drugs and therapy have multiple side effects, which causes heart related issues, headache, dizziness, anorexia, cramping of legs and gastrointestinal related problem, particularly pain in stomach and heartburn [3]. The research still continues for the enhancement of such benefit to lower risk involved in human beings.

Anabolic or osteogenic therapies are preferred for pharmacological development to treat osteoporosis [4]. Parathyroid hormone (PTH 1-34) only anabolic agent for the treatment of postmenopausal osteoporosis that is also recommended by the FDA (Food and Drug Administration) which regulates the formation of bones by enhancing the cell proliferation of the osteoblastic lineage or inducing differentiation of osteoblast progenitor cells. 
Whilst, this therapy is also related to an increased risk of cancer, such as osteosarcoma $[5,6]$.

In the recent time, several medicinal plants are used for health care treatments and management especially bone related diseases. Although compared with other drug treatments, herbal products create no/little side effects. Punica granatum (Pomegranate, PG) is one of the most potent fruit-bearing medicinal herbs widely distributed throughout the Mediterranean region of southern Europe, northern Africa and tropical Africa, Indian subcontinent, Central Asia and the drier parts of South-East Asia. PG seeds contain punicic acid, ellagic acid, steroidal estrogen and non-steroidal phytoestrogens, including comesten, coumoestrol and isoflavones genistein, daidzein and ascorbic acids. PG also contains estrogenic compound such as luteolin, quercetin, kaempferol, estrone and estradiol, which are responsible for bone formation and also inhibit the resorption process [7-12]. A nonisoflavone phytoestrogenic compounds such as quercetin, rutin, apigenin and coumestrol has also been reported in various legumes [13]. A crude PG extract and its seed oil enhance bone healing properties and prevent loss of bones because of the proliferation of osteoblast, inhibition of osteoclast cell and also decrease the inflammation. $[14,15]$. Recently, PG has been also utilized to inhibit acetyl cholinesterase activity as a new source for management of Alzheimer's disease [16].

Osteoblast differentiation and proliferation mediated by different growth factors such as bone morphogenetic proteins (BMPs), transforming growth factor beta (TGF $\beta$ ) and core-binding factor alpha1 (Cbfo1) are known to be targeted the osteogenic Runt-related transcription factor2 (Runx2) gene [17]. Runx2 is the key transcription factor initiating and regulating the early osteogenesis and late mineralization of bone. Furthermore, Runx 2 triggers the expression of major bone matrix genes during the early stages of osteoblast differentiation [18].

There is no evidence regarding the investigation of the PG seed extract on bone cell proliferation, differentiation, and collagen matrix formation in primary culture of osteoblasts. The present study also described the matrix mineralization activity along with osteogenic gene Runx2 expression by real time PCR and DNA content analysis in the $\mathrm{S}$ phase of the cell cycle in osteoblastic cells. The findings suggested that PG may be a potent osteogenic herbal drug that induces bone cells proliferation and regeneration following increased DNA contents and Runx2 gene expression which provide future prospects in the development of anti-osteoporotic drugs and therapy.

\section{Materials and methods}

Reagents and chemicals

Alpha modified minimum essential medium ( $\alpha$-MEM), fetal bovine serum (FBS), MTT (3-(4,5-dimethylthiazol- 2-yl) -2,5-diphenyltetrazolium bromide) dye, $p$-nitrophenyl phosphate (pNPP), naphthol ASMX phosphate, fast blue BB salt, ascorbic acid and Sirius Red dye were purchased from Himedia, India. $\beta$-glycerophosphate, Ribonuclease (RNase) A and propidium iodide (PI) were purchased from Sigma-Aldrich, USA. RNAiso Plus reagent was procured from Takara, India. cDNA synthesis kit was purchased from Thermo Scientific, USA and SYBER green kit from Roche, USA. All the reagents used were of high purity grade.

\section{Plant materials and extraction}

The fresh cultivated PG plant was collected from nearby University of Lucknow, Lucknow, India. Plant materials were identified and authenticated from Department of Pharmacognosy, Faculty of Pharmacy, Integral University, Lucknow. A reference specimen (voucher No. IU/PHAR/ HRB/14/08) has been deposited in the herbarium of Faculty of Pharmacy, Integral University, Lucknow. Seed parts of collecting plant were air dried in the shade and crushed to a powder in a mechanical grinder. The $95 \%$ ethanolic extract of PG was prepared with the help of Soxhlet apparatus (Borosil Glass Works Limited, India) at $60^{\circ} \mathrm{C}$ and Whatman No. 1 filter paper was used to obtain filtrate of extract. The filtrate was concentrated in vacuum at $40^{\circ} \mathrm{C}$ using a rotary evaporator (BUCHI Rotavapor R-205, Switzerland).

\section{Primary culture of osteoblasts}

Osteoblastic cells were isolated from neonatal rat pups calvaria using sequential digestion with slight modification [19]. Briefly, calvaria were dissected from four to five neonatal (1-2 days old) rat pups. After removal of sutures and adherent mesenchymal tissues, calvaria were subjected to five sequential (10-15 $\mathrm{min})$ digestions at $37^{\circ} \mathrm{C}$ in shaking water bath at $120 \mathrm{rpm}$ containing each of $0.1 \%$ dispase and collagenase type II enzymes. Supernatants were pooled from the second to fifth digestions in a tube containing $800 \mu \mathrm{l} \mathrm{FBS.} \mathrm{Cells} \mathrm{were} \mathrm{re-suspended}$ in $\alpha$-MEM containing $10 \%$ FBS with $1 \%$ penicillin/streptomycin solution and transfer in $\mathrm{T}-25 \mathrm{~cm}^{2}$ culture flasks. The flasks were incubated at $37^{\circ} \mathrm{C}$ with $5 \% \mathrm{CO}_{2}$ in $\mathrm{CO}_{2}$ incubator (Excella ECO-170, New Brunswick). The study was approved by the Institutional Animal Ethics Committee of Azad Institute of Pharmacy and Research, Lucknow (Ref. No.: AIPR/2013-14/1398).

\section{Cell proliferation}

The proliferative effect of PG extract was determined using MTT assay with some modification [20]. Calvarial osteoblasts were suspended in $\alpha$-MEM medium and plated at a density of $2 \times 10^{3}$ cells/well in a 96 wells plate. After overnight incubation, the medium was replaced with a medium containing PG extract solution prepared in media with 
different concentrations $(0,10,25,50$ and $100 \mu \mathrm{g} / \mathrm{ml})$ in triplicate for $48 \mathrm{~h}$. 17 $\beta$-estradiol (E2) at the concentration of $1 \mathrm{nM}$ was used as a positive control. After exposure period, $10 \mu \mathrm{l}$ of $5 \mathrm{mg} / \mathrm{ml}$ MTT solution was added to each wells and further incubated at $37^{\circ} \mathrm{C}$. After $4 \mathrm{~h}$, medium was discarded and $100 \mu \mathrm{l}$ of dimethyl sulphoxide (DMSO) was added to solubilise the dark blue formazan crystals at $37^{\circ} \mathrm{C}$ for $10 \mathrm{~min}$. Absorbance was recorded at $540 \mathrm{~nm}$ with microplate reader (BIORAD-680, USA) and the percentage viable cells were calculated using the formula:

$\%$ Cell viability $=[(\mathrm{OD}$ of treated $) /(\mathrm{OD}$ of control $)] \times 100$

The cellular morphology was also observed in other sets of PG treatment under trinocular inverted phase contrast microscopy (Nikon ECLIPSE Ti-S, Japan).

\section{Alkaline phosphatase (ALP) activity}

ALP assay is based on the hydrolysis of pNPP by ALP into a yellow colored product at alkaline $\mathrm{pH}$. ALP activity of osteoblasts was determined with a slight modification [21]. A $100 \mu \mathrm{l}$ of cell suspension containing $2 \times 10^{3}$ cells /well was seeded in 96-well plates using $\alpha$-MEM supplemented with $10 \% \mathrm{FBS}, 10 \mathrm{mM} \beta$-glycerophosphate, $50 \mu \mathrm{g} /$ $\mathrm{ml}$ ascorbic acid and 1\% penicillin/streptomycin (osteoblast differentiation medium) and treated with different concentrations $(10-100 \mu \mathrm{g} / \mathrm{ml})$ of the extract for $48 \mathrm{~h}$. E2 at the concentration of $1 \mathrm{nM}$ was used as a positive control. After completion of incubation period, osteoblast cultures were fixed in $4 \%$ paraformaldehyde and stained with a solution containing $0.1 \mathrm{mg} / \mathrm{ml}$ naphthol ASMX phosphate, $0.5 \% \mathrm{~N}, \mathrm{~N}$ - dimethylformamide, $2 \mathrm{mM} \mathrm{MgCl} 2$, and $0.6 \mathrm{mg} / \mathrm{ml}$ of fast blue $\mathrm{BB}$ salt in $0.1 \mathrm{mM}$ Tris- $\mathrm{HCl}$ (pH 8.5) for $20 \mathrm{~min}$. The formation of color was examined and images were taken under an inverted phase contrast microscope. For the quantitative estimation of ALP, the plate was fixed and kept in $-70^{\circ} \mathrm{C}$ for $20 \mathrm{~min}$, and then brought to $37^{\circ} \mathrm{C}$ for freeze fracture. Next, $50 \mu$ of chilled $p$-nitrophenyl phosphate (pNPP) substrate was added to each wells and incubated at $37^{\circ} \mathrm{C}$ for $30 \mathrm{~min}$ for color development. The absorbance was measured at $405 \mathrm{nM}$ using an ELISA reader.

\section{Assessment of collagen deposition}

Sirius Red is an anionic dye that binds strongly to collagen molecules. Collagen deposition was quantified using Sirius Red dye following slightly modification [22]. Treated cells were washed with $\mathrm{PBS}$ and dried at $37^{\circ} \mathrm{C}$ in 96-wells plate for overnight incubation and then stained with $20 \mu \mathrm{l}$ of Sirius Red dye $(0.1 \%$ in saturated picric acid) for $1 \mathrm{~h}$ with mild shaking. Sirius Red dye solution ( $\mathrm{pH} 3.5)$ was prepared in saturated aqueous picric acid $\left(1.3 \%\right.$ in $\left.\mathrm{H}_{2} \mathrm{O}\right)$ at a concentration of $0.1 \mathrm{mg} / \mathrm{ml}$. The stained cell layers were extensively washed with $0.01 \mathrm{~N} \mathrm{HCl}$ to remove all non- bounded dye. After rinsing, photographs were taken under inverted phase contrast microscope. For quantitative analysis, the stained cells were dissolved in $0.2 \mathrm{ml} 0.1 \mathrm{~N}$ $\mathrm{NaOH}$ at shaker for $30 \mathrm{~min}$. Next, absorbance was measured colorimetrically at $550 \mathrm{~nm}$ against $0.1 \mathrm{~N} \mathrm{NaOH}$ serve as a blank.

\section{Mineralization assay}

Alizarin Red S, an anthraquinone derivative, was used to identify calcium content in osteoblasts according to a method reported previously [23]. Approximately, $2 \times 10^{4}$ cells/well were seeded in 12-wells culture plate in osteoblast differentiation medium with $10^{-7} \mathrm{M}$ dexamethasone. Cells were treated with PG extract at various concentrations $(10-100 \mu \mathrm{g} / \mathrm{ml})$ for 21 days and the medium was changed every alternate day. At the end of the experiment, cells were washed with PBS and fixed with 4\% paraformaldehyde in PBS for $15 \mathrm{~min}$. The fixed cells were stained with $40 \mathrm{mM}$ Alizarin Red-S (pH 4.5) for 30 min followed by washing with distilled water. Calcified nodules appearing as bright red color were photographed under inverted phase contrast microscopy. For quantification of staining, $100 \mathrm{mM}$ cetylpyridinium chloride solution was added for $1 \mathrm{~h}$ in each well to solubilise and to release calciumbound alizarin red into solution. A $100 \mu \mathrm{l}$ of the supernatant from each well were transferred in 96 well plate in triplicate and the absorbance was recorded at $570 \mathrm{~nm}$ by a microplate reader.

\section{Cellular DNA content}

Cell cycle phase distribution with cellular DNA content was analyzed using flow cytometry with some modification [24]. Osteoblasts were planted in 6-wells plate at a density $1 \times 10^{6}$ cells/well and treated with different concentrations $(10-100 \mu \mathrm{g} / \mathrm{ml})$ of extract for $48 \mathrm{~h}$. E2 at the concentration of $10 \mathrm{nM}$ was used as a positive control. Cultured cells were washed with cold PBS and fixed in $70 \%$ ethanol at $-20^{\circ} \mathrm{C}$ for $2 \mathrm{~h}$. Fixed cells were treated with RNase A $(10 \mathrm{mg} / \mathrm{ml})$ and stained with PI dye in the dark for $30 \mathrm{~min}$ at room temperature. The PI dye fluorescence of individual nuclei was measured by using a flow cytometer (BD FACS Calibur, Becton Dickinson, USA) and data were analyzed using Cell Quest Pro V 3.2.1 software (Becton Dickinson, USA).

\section{Quantitative real-time PCR (qPCR)}

The total RNA was isolated from cultured osteoblasts treated with PG extract using RNAiso Plus reagent. Aliquots of $2.0 \mu \mathrm{g}$ of total RNA in a $10 \mu \mathrm{l}$ reaction volume were subjected to PCR using a cDNA synthesis kit. Quantitative real-time PCR was performed in light cycler PCR system (LightCycler 480, Roche, USA) using SYBER green kit following manufacturer's instruction. Runx2 gene expression in calvarial osteoblasts was determined 
by qPCR using an optimized protocol [25]. Sequence of primer pairs of the genes used in the present study were; runx2- CCACAGAGCTATTAAAGTGACAGTG (F), AACAAACTAGGTTTAGAGTCATCAAGC (R) and GAPDH (housekeeping gene) - CAGCAAGGATACTGA GAGCAAGAG (F), GGATGGAATTGTGAGGGAGATG (R). All the data were normalized to GAPDH expression to study the relative expression of the targeted gene.

\section{Statistics}

All results were represented as the means \pm SEM of results from all replicates and statistically significance was determined by one-way analysis of variance (ANOVA) followed by Dunnett's multiple comparison tests. Probability values of $\mathrm{p}<0.05$ were considered to be statistically significant. All analysis was conducted using the Graph Pad Prism (Ver. 5.1) software.

\section{Results and discussion}

\section{Microscopic observation of osteoblastic cells}

The morphological changes of untreated (control) and treated osteoblasts with different concentrations of PG extract at $48 \mathrm{~h}$ are shown in Figure 1A. The typical spindle shaped with fibroblastic appearance was observed in control under inverted phase contrast microscope. The concentrations 10 and $25 \mu \mathrm{g} / \mathrm{ml}$ of extract enhanced the cell proliferation, moreover, 50 and $100 \mu \mathrm{g} / \mathrm{ml}$ of PG showed the more dense appearance with increased number of cells as compared to control that attributed differentiation of osteoblastic cells. The results revealed that cells exposed to PG extract induce differentiation of osteoblasts as a function of dose due to their morphological alterations and number of cells increment [26].

\section{Effect of PG on the cell proliferation of osteoblasts}

The effect of different doses $(10-100 \mu \mathrm{g} / \mathrm{ml})$ of PG extract on osteoblastic cell proliferation was tested at $48 \mathrm{~h}$ (Figure 1B). As compared to control group (cells without extract treatment), PG significantly increased the cell proliferation to $13.03(\mathrm{p}<0.05)$ and $24.28 \%(\mathrm{p}<0.001)$ at 10 and $25 \mu \mathrm{g} / \mathrm{ml}$, respectively. Moreover, 50 and $100 \mu \mathrm{g} /$ $\mathrm{ml}$ of PG extract induced cell proliferation to 39.64 and $62.59 \%(\mathrm{p}<0.001)$ respectively. The results revealed that PG extract induced the significant cell proliferation in a dose dependent manner. Exposure of cells to $1 \mathrm{nM}$ of $17 \beta$-estradiol as a positive control, increased the cell proliferation to $41.72 \%(\mathrm{p}<0.001)$ as compared to control. The proliferative effects of PG extract might be due to their estrogenic nature of its contents, including quercetin, kaempferol, estrone and estradiol, which promote bone cell proliferation [11]. A study has shown that PG promoted osteoblast MC3T3-E1 cell proliferation up to approximately 2-fold at $250 \mu \mathrm{g} / \mathrm{ml}$ of plant extracts [7]. Both osteoblast and MCF-7 (human breast adenocarcinoma) cells are an estrogen receptor positive $\left(\mathrm{ER}^{+}\right)$cells. A similar study has also revealed that MCF-7 cells exposed to legume extracts containing quercetin, daidzein, genistein and kaempferol glycosides at various concentrations $(1-1000 \mu \mathrm{g} / \mathrm{ml})$ showed a maximum cell proliferation at $100 \mu \mathrm{g} / \mathrm{ml}$ of the extracts [27].

\section{Effect of PG on ALP activity of osteoblasts}

Quantitative estimation of alkaline phosphatase activity is one of the biochemical methods, which described the early cell differentiation of osteoblastic cells [28]. Fast blue BB salt-ASMX-phosphate complex acted on ALP activity which appeared to be blue in color. The qualitative data showed that PG extract stimulated ALP stain by increasing the rate of osteoblast cell differentiation in a dose dependent manner (Figure 2A). As observed from numerical data (Figure 2B), concentrations 10 and $25 \mu \mathrm{g} /$ $\mathrm{ml}$ of extract induced ALP level to $9.66 \%(\mathrm{p}<0.05)$ and $22.49 \%(\mathrm{p}<0.01)$ significantly as compared to control. Also, 50 and $100 \mu \mathrm{g} / \mathrm{ml}$ of extract induced the significant ALP level to 34.67 and $43.95 \%(\mathrm{p}<0.01)$ respectively as compared to control. Exposure of cells to $1 \mathrm{nM}$ of E2 increased ALP activity to $36.66 \%$ ( $\mathrm{p}<0.01)$ as compared to control. Results of ALP assay were the consistent with
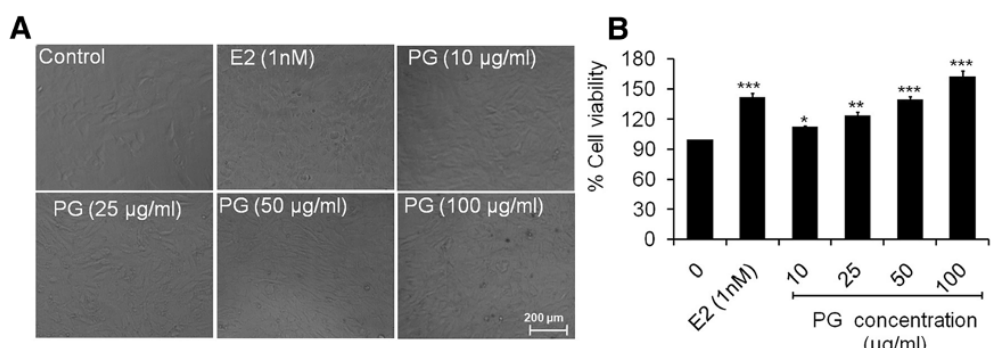

Figure 1 Percent cell proliferation of primary osteoblasts. (A) Morphology of osteoblasts under inverted phase contrast microscope treated with different concentrations of PG extract at $48 \mathrm{~h}$ (B) Percent cell proliferation of osteoblasts treated with 10-100 $\mu \mathrm{g} / \mathrm{ml}$ of PG extract. Values were obtained from three independent experiments and expressed as mean $\pm \mathrm{SEM} .{ }^{*} \mathrm{p}<0.05,{ }^{* * *} \mathrm{p}<0.01$ and ${ }^{* * *} \mathrm{p}<0.001$ as compared with control. 


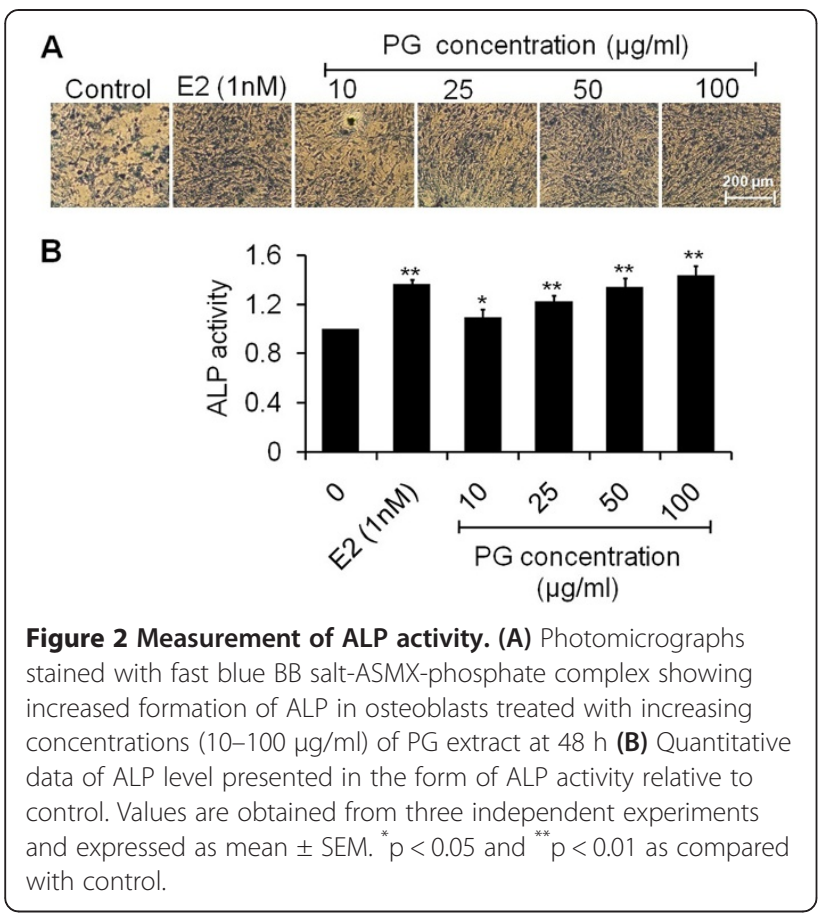

MTT assay data which suggested that cell proliferation also correlate with cell differentiation. These results indicate that PG extract induces regeneration of osteoblasts as a function of dose might be due to the presence of estrogenic compounds. PG containing estrogenic compounds daidzein and genistein has been reported to possess stimulatory effects synthesizing alkaline phosphatase by osteoblasts in vitro [29].

\section{Effect of PG on collagen deposition by osteoblasts}

Sirius Red stain was used to assess the extent of collagen (predominantly collagen type I and III fibers) deposited by osteoblasts which developed dense and cross-linked collagen. Collagen comprises $85-90 \%$ of the total organic bone matrix [30]. Histological analysis showed that PG extract increases collagen content in osteoblasts in a dose dependent manner as compared to control. PG extract exposed on cells was able to enhance in the collagen density significantly as evident by dark red clusters of collagen evenly distributed throughout the stimulated region (Figure 3A). Further, quantitative measurement of the Sirius Red staining intensity in osteoblasts culture showed a significant increment of 24.96 ( $p<0.01), 62.40$, 89.37 and $129.84 \%(\mathrm{p}<0.001)$ of collagen secretion at $10,25,50$ and $100 \mu \mathrm{g} / \mathrm{ml}$ of PG exposure, respectively as compared to control (Figure 3B). Exposure of osteoblasts to $1 \mathrm{nM}$ of E2 increased the collagen content to only $77.95 \%(\mathrm{p}<0.001)$ as compared to control. Bone shows a variety of structural organizations which is related to the balance between the amount of collagen

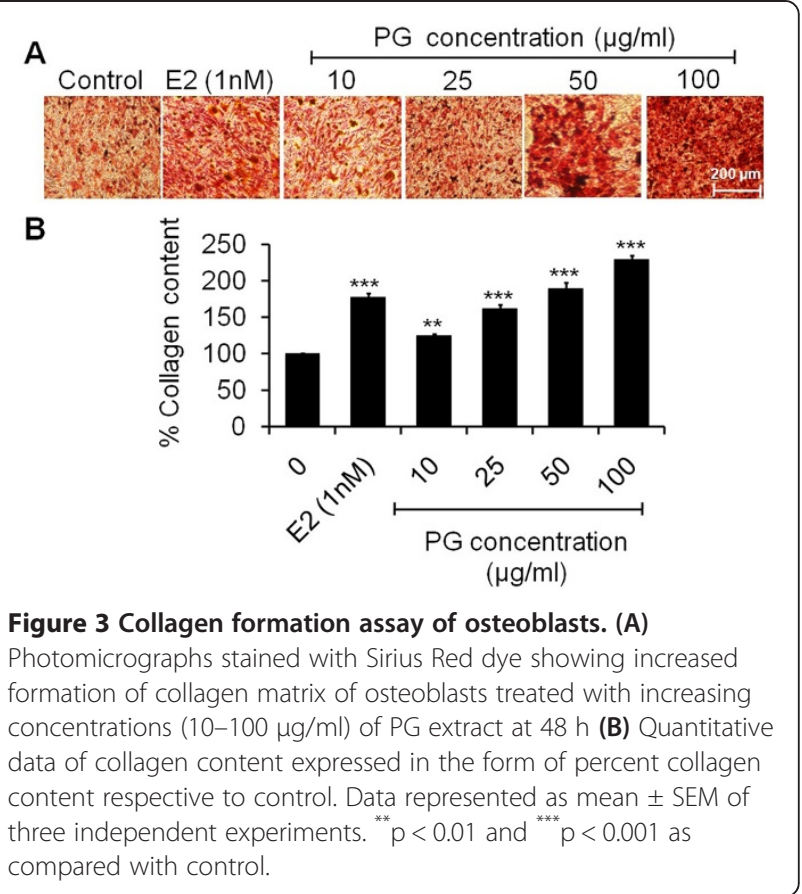

and mineral [31]. However, not only mineral matrix deposition is essential to ensure a healthy bone, giving strength and rigidity in the skeletal system, but also the adequate deposition of organic matrix (collagen) contributes to bone architecture. Therefore, experiments were conducted to determine whether PG extract exposure enhances the organic matrix deposition. PG treated osteoblasts progressively deposited more collagen (Figure 3A and $\mathrm{B}$ ) suggesting the collagen deposition induced by PG is a function of dose. A study has reported that ascorbic acid stimulates the formation of collagen matrix at multiple levels, including gene expression, hydroxylation of proline and lysine in collagen during post-translational modification [32].

\section{Effect of PG on osteoblast mineralization}

Mineralized nodule formation describes the final stages of osteoblastic differentiation at 21 days. As observed from photomicrographs, osteoblastic cells in proliferation period exhibited a fibroblastic morphology monolayer in control cells. As the progress in mineralization, the cells continued growing slowly and formed a mosaic like multiple layers which was greater at $100 \mu \mathrm{g} / \mathrm{ml}$ of PG extract (Figure 4A). The percent calcification data of Alizarin stain showed that treatment of osteoblasts at $10,25,50$ and $100 \mu \mathrm{g} / \mathrm{ml}$ of extract significantly increased mineralized nodule formation that signifying by 26.15 ( $\mathrm{p}<0.01), 44.55,65.64$ and $82.81 \%$ ( $\mathrm{p}<0.001)$, respectively as compared to control (Figure 4B). Exposure of 


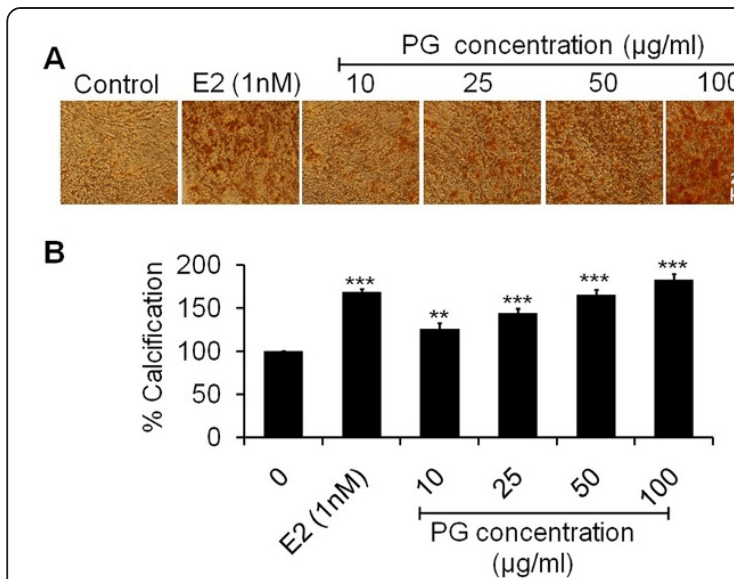

Figure 4 Mineralization assay of osteoblasts. (A) Photomicrographs stained with Alizarin Red S showing increased formation of mineralized nodules of osteoblasts treated with increasing concentrations $(10-100 \mu \mathrm{g} / \mathrm{ml}$ ) of PG extract at 21 days (B) Quantitative data of Alizarin Red-S extraction expressed in the form of percent calcification. Data represented as mean \pm SEM of three independent experiments. ${ }^{* *} p<0.01$ and ${ }^{* * *} p<0.001$ as compared with control.

osteoblasts to $1 \mathrm{nM}$ of E2 increased the mineralization content to $68.85 \%(\mathrm{p}<0.001)$ as compared to control. Increased mineralization is synonymous to increased calcium deposition. The ability to form an extracellular matrix that can undergo regulated mineralization is the ultimate phenotypic expression of an osteogenic tissue [33]. PG treatment increased the calcium content notably in the mineralized matrix at 21 days of osteoblasts when compared with untreated cells. In this context, the phytoestrogen genistein has been previously found to stimulate bone mineralization in vitro [34].

\section{Effect of PG on cellular DNA content and cell cycle distribution of osteoblasts}

The cellular DNA content and proportion of cells in different phases of the cell cycle was analyzed by using flow cytometry. Osteoblastic cells were treated with one lower $(25 \mu \mathrm{g} / \mathrm{ml})$ and one higher concentration $(100 \mu \mathrm{g} / \mathrm{ml})$ of the PG extract for $48 \mathrm{~h}$ and observed the different phases of the cell cycle. As evident from the results (Figure 5), a normal distribution of cell cycle was observed in the control group. At $25 \mu \mathrm{g} / \mathrm{ml}$ of PG extract, the accumulation of cells (DNA content) in S phase was sharply increased from 12.67 to $31.54 \%$ as compared to control. Moreover, $100 \mu \mathrm{g} / \mathrm{ml}$ concentration of the extract resulted to an incredible increment of DNA content in S phase by $78.72 \%$ as compared to control. Exposure of osteoblasts to $1 \mathrm{nM}$ of E2 increased the DNA content in S phase by $44.08 \%$ greater at $25 \mu \mathrm{g} / \mathrm{ml}$ of PG treatment. These data indicate that the PG extract induce the cell proliferation by accumulating the DNA content in S phase of the cell cycle. A similar study has reported that estradiol induced the expression of estrogen receptor by promoting $\mathrm{S}$ phase of cell cycle in human osteosarcoma cell lines and pilose antler polypeptides promoted chondrocytes proliferation by accelerating cell cycle progression in S phase $[35,24]$.

\section{Effect of PG on osteogenic gene runx2 expression}

To determine these results could be extended to another protein present in the organic bone matrix and effect of PG on the expression of Runx2 gene. Runx2 is a noncollagenous, highly conserved transcription factor involved in the regulation of mineralized matrix of bone. Increased expression of osteogenic gene was observed by qPCR in osteoblasts treated with PG extract at $48 \mathrm{~h}$. As cleared from results (Figure 6), $10 \mu \mathrm{g} / \mathrm{ml}$ of PG extract significantly elevated the Runx 2 expression as compared to

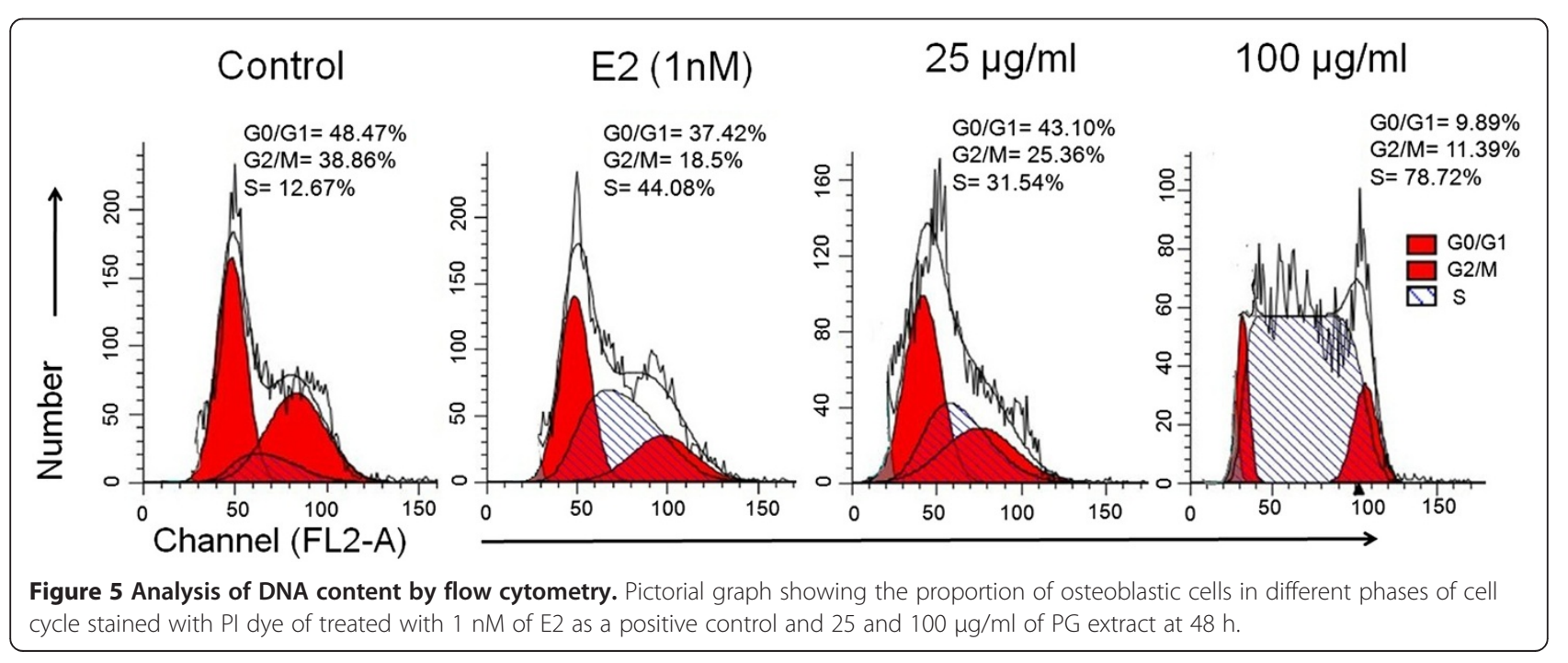




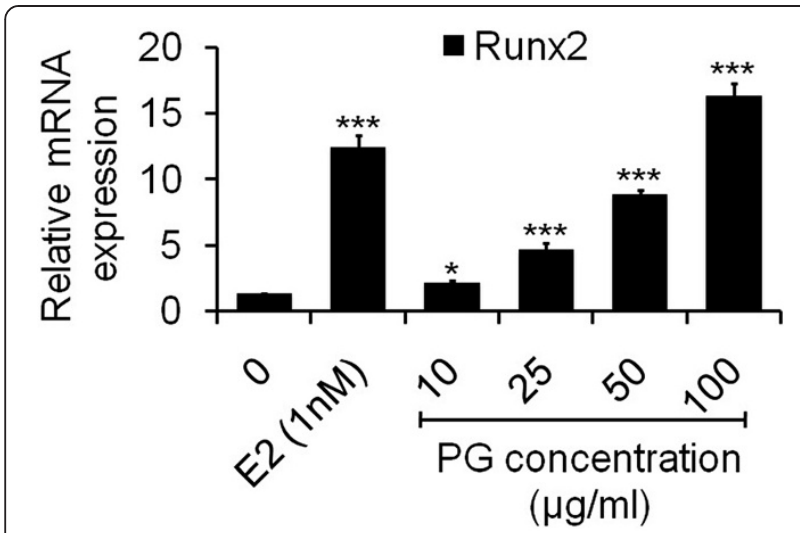

Figure 6 Analysis of mRNA levels of Runx2 gene by qPCR. Osteoblasts were treated with (10-100 $\mu \mathrm{g} / \mathrm{ml})$ of PG for $48 \mathrm{~h}$. qPCR for Runx2 mRNAs was performed. At each concentration, PG increased the mRNA levels when compared to control. Fold changes in mRNA levels are indicated by the numbers derived after normalizing with GAPDH mRNA levels used as an internal control. Values are obtained from three independent experiments in triplicate and expressed as mean \pm SEM; ${ }^{*} p<0.05,{ }^{*} p<0.01$ and ${ }^{* * *} p<0.001$ as compared with control.

control $(\mathrm{p}<0.05)$. Moreover, concentrations 25,50 and $100 \mu \mathrm{g} / \mathrm{ml}$ of PG increased the remarkable Runx2 level in a dose dependent manner $(\mathrm{p}<0.001)$ as compared to control. It has been reported that Runx2 bonds to the osteoblast specific cis acting element which is found in the promoter region of all major osteoblast specific genes like osteocalcin, type-I collagen, BSP, OPN, ALP and control their expression [36]. Hence, it is reasonable to speculate that the estrogenic compounds such as $\beta$-sitosterol present in PG could have acted in a manner to induce mRNA expression of ALP, collagen and their protein levels and consequently increased Runx 2 gene expression in osteoblastic cells. Furthermore, flavonoids have also been shown to increase the expression of Runx2 $[37,38]$. Thus, $\beta$-sitosterol and flavonoids present in PG might be responsible for the increased expression and transcriptional activity of Runx2.

\section{Conclusion}

The present study showed that osteogenic potential of PG extract in primary calvaria osteoblasts is based on two salient features. (1) Cytochemical studies including cell proliferation, ALP stain, collagenation, matrix mineralization and DNA content in the $S$ phase of the cell cycle in osteoblasts are the key parameters, which favor the osteogenic potential of PG. (2) A molecular marker Runx2 is a highly conserved osteogenic transcription factor involved in the regulation of bone cells proliferation and differentiation, which is also favors the osteogenic nature of PG.
Even though E2 used as a positive control shows the slightly higher effect on the proliferation, differentiation, collagenation, mineralization, DNA content and Runx2 gene expression of osteoblasts than lower doses, however, the side effects of the long-term use of estrogen, such as a higher incidence of endometrial cancer, cardiovascular disease and breast carcinoma, could not be ignored.

Thus, the results from this study suggest that PG promotes the function of osteoblasts and plays an important role in remodeling of the bone, which indicated that it may be one of anti-osteoporotic herbal candidate free from side effects. Accordingly, PG might be useful for alternative pharmacological agent of osteoporosis and skeletal tissues may benefit from the consumption of PG.

\section{Abbreviations}

ALP: Alkaline phosphatase; a-MEM: Alpha modified minimum essential medium; E2: 17ß-estradiol; BMPs: Bone morphogenetic proteins; Cbfa1: Core-binding factor alpha-1; DMSO: Dimethyl sulfoxide; ELISA: Enzyme linked immunosorbent assay; FBS: Fetal bovine serum; FDA: Food and drug administration; HRT: Hormone replacement therapy; MTT: (3-(4,5dimethylthiazol-2-yl)-2,5-diphenyltetrazolium bromide); PBS: Phosphate buffered saline; PG: Punica granatum; pNPP: p-nitrophenyl phosphate; PTH: Parathyroid hormone; PI: Propidium iodide; qPCR: Quantitative real-time PCR; Runx2: Runt-related transcription factor 2; SEM: Standard error mean; SERMs: Selective estrogen receptor modulators; TGF $\beta$ : Transforming growth factors.

\section{Competing interests}

The authors declare that they have no competing interests.

\section{Authors' contributions}

SS and MA participated in the design of the study. SS performed the experimental work and data interpretation. SS and MA involved in review of the paper. Both authors read and approved the final version of the manuscript.

\section{Authors' information}

Sahabjada Siddiqui, M.Sc. in Biotechnology; Md Arshad, Ph.D. in Endocrinology, CDRI, Lucknow and Assistant Professor at University of Lucknow.

\section{Acknowledgments}

Authors are thankful to UGC Major Research Project File No. 37-436/2009 (SR), New Delhi, India for financial support. Author Sahabjada Siddiqui is thankful to ICMR, New Delhi, India for the award of Senior Research Fellowship (No. 45/26/2013/BMS/TRM). Authors are thankful to the Director, Azad Institute of Pharmacy and Research, Lucknow for providing research facilities for animal experiment.

Received: 3 August 2014 Accepted: 1 November 2014 Published online: 20 November 2014

\section{References}

1. Kaunitz AM, Mcclung MR, Feldman RG: Post menopausal osteoporosis: fracture risk and prevention. J Fam Pract 2009, 58:S1-S6.

2. Maclaughlin EJ, Sleeper RB, McNatty D, Raehl CL: Management of age-related osteoporosis and prevention of associated fractures. Ther Clin Risk Manag 2006, 2:281-295.

3. Rizzoli R, Reginster JY, Boonen S, Bréart G, Diez-Perez A, Felsenberg D, Kaufman JM, Kanis JA, Cooper C: Adverse reactions and drug-drug interactions in the management of women with postmenopausal osteoporosis. Calcif Tissue Int 2011, 89:91-104.

4. Dixit P, Khan MP, Swarnkar G, Chattopadhyay N, Maurya R: Osteogenic constituents from pterospermum acerifolium willd. Flowers. Bioorg Med Chem Lett 2011, 21:4617-4621. 
5. John MR, Arai M, Rubin DA, Jonsson KB, Jüppner $\mathrm{H}$ : Identification and characterization of the murine and human gene encoding the tuberoinfundibular peptide of 39 residues. Endocrinology 2002, 143:1047-1057.

6. Wang W, Olson D, Cheng B, Guo X, Wang K: Sanguis Draconis resin stimulates osteoblast alkaline phosphatase activity and mineralization in MC3T3-E1 cells. J Ethnopharmacol 2012, 142:168-174.

7. Kim YH, Choi EM: Stimulation of osteoblastic differentiation and inhibition of interleukin- 6 and nitric oxide in MC3T3-E1 cells by pomegranate ethanol extract. Phytother Res 2009, 23:737-739.

8. van Elswijk DA, Schobel UP, Lansky EP, Irth H, van der Greef J: Rapid dereplication of estrogenic compounds in pomegranate (punica granatum) using on-line biochemical detection coupled to mass spectrometry. Phytochemistry 2004, 65:233-241.

9. Trivedi R, Kumar A, Gupta V, Kumar S, Nagar GK, Romero JR, Dwivedi AK, Chattopadhyay N: Effects of Egb 761 on bone mineral density, bone microstructure, and osteoblast function: Possible roles of quercetin and kaempferol. Mol Cell Endocrinol 2009, 302:86-91.

10. Heftmann E, Ko ST, Bennett RD: Identification of estrone in pomegranate seeds. Phytochemistry 1966, 5:1337-1339.

11. Jurenka J: Therapeutic applications of pomegranate (punica granatum L.): a review. Alterm Med Rev 2008, 13:128-144.

12. Pérez-Vicente A, Gil-Izquierdo A, García-Viguera C: In vitro gastrointestinal digestion study of pomegranate juice phenolic compounds, anthocyanins, and vitamin C. J Agric Food Chem 2002, 50:2308-2312.

13. Konar N: Non-isoflavone phytoestrogenic compound contents of various legumes. Eur Food Res Technol 2013, 236:523-530.

14. Spilmont M, Léotoing L, Davicco MJ, Lebecque P, Mercier S, Miot-Noirault E, Pilet $P$, Rios $L$, Wittrant $Y$, Coxam V: Pomegranate seed oil prevents bone loss in a mice model of osteoporosis, through osteoblastic stimulation, osteoclastic inhibition and decreased inflammatory status. J Nutr Biochem 2013, 24:1840-1848.

15. Mori-Okamoto J, Otawara-Hamamoto $\mathrm{Y}$, Yamato $\mathrm{H}$, Yoshimura $\mathrm{H}$ : Pomegranate extract improves a depressive state and bone properties in menopausal syndrome model ovariectomized mice. J Ethnopharmacol 2004, 92:93-101.

16. Jazayeri SB, Amanlou A, Ghanadian N, Pasalar P, Amanlou M: A preliminary investigation of anticholinesterase activity of some Iranian medicinal plants commonly used in traditional medicine. Daru 2014, 22:17.

17. Yamaguchi A, Komori T, Suda T: Regulation of osteoblast differentiation mediated by bone morphogenetic proteins, hedgehogs, and Cbfa1. Endocr Rev 2000, 21:393-411.

18. Komori T: Regulation of osteoblast differentiation by Runx2. Adv Exp Med Biol 2010, 658:43-49

19. Orriss IR, Taylor SE, Arnett TR: Rat osteoblast cultures. Methods Mol Biol 2012, 816:31-41

20. Ashfaq M, Singh S, Sharma A, Verma N: Cytotoxic evaluation of the hierarchal web of carbon micro-nanofibers. Ind Eng Chem Res 2013, 52:4672-4682

21. Moutahir-Belqasmi F, Balmain N, Lieberrher M, Borzeix S, Berland S, Barthelemy M, Peduzzi J, Milet C, Lopez E: Effect of water soluble extract of nacre (pinctada maxima) on alkaline phosphatase activity and $\mathrm{Bcl}-2$ expression in primary cultured osteoblasts from neonatal rat calvaria. J Mater Sci Mater Med 2001, 12:1-6.

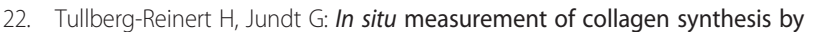
human bone cells with a sirius red-based colorimetric microassay: effects of transforming growth factor beta2 and ascorbic acid 2-phosphate. Histochem Cell Biol 1999, 112:271-276.

23. Weivoda MM, Hohl RJ: Effects of farnesyl pyrophosphate accumulation on calvarial osteoblast differentiation. Endocrinology 2011, 152:3113-3122.

24. Lin JH, Deng LX, Wu ZY, Chen L, Zhang L: Pilose antler polypeptides promote chondrocyte proliferation via the tyrosine kinase signaling pathway. J Occup Med Toxicol 2011, 6:27.

25. Dixit $P$, Chand K, Khan MP, Siddiqui JA, Tewari D, Ngueguim FT, Chattopadhyay N, Maurya R: Phytoceramides and acylated phytosterol glucosides from pterospermum acerifolium willd. Seed coat and their osteogenic activity. Phytochemistry 2012, 81:117-125.

26. Abiramasundari $G$, Sumalatha KR, Sreepriya M: Effects of tinospora cordifolia (menispermaceae) on the proliferation, osteogenic differentiation and mineralization of osteoblast model systems in vitro. J Ethnopharmacol 2012, 141:474-480.
27. Zhao QW, Li B, Weber N, Lou YJ: Estrogen-like effects of ethanol extracts from several Chinese legumes on MCF-7 cell. Eur Food Res Technol 2005, 221:828-833.

28. Bhargavan B, Gautam AK, Singh D, Kumar A, Chaurasia S, Tyagi AM, Yadav DK, Mishra JS, Singh AB, Sanyal S, Goel A, Maurya R, Chattopadhyay N: Methoxylated isoflavones, cajanin and isoformononetin, have non-estrogenic bone forming effect via differential mitogen activated protein kinase (MAPK) signalling. J Cell Biochem 2009, 108:388-399.

29. Sugimoto $E$, Yamaguchi M: Stimulatory effect of daidzein in osteoblastic MC3T3-E1 cells. Biochem Pharmacol 2000, 259:471-475.

30. Sasano Y, Li HC, Zhu JX, Imanaka-Yoshida K, Mizoguchi I, Kagayama M: Immunohistochemical localization of type I collagen, fibronectin and tenascin C during embryonic osteogenesis in the dentary of mandibles and tibias in rats. Histochem J 2000, 32:591-598.

31. Landis WJ: The strength of a calcified tissue depends in part on the molecular structure and organization of its constituent mineral crystals in their organic matrix. Bone 1995, 16:533-544.

32. Franceschi RT, lyer BS, Cui Y: Effects of ascorbic acid on collagen matrix formation and osteoblast differentiation in murine MC3T3-E1 cells. J Bone Miner Res 1994, 9:843-854.

33. Muthusami S, Senthilkumar K, Vignesh C, llangovan R, Stanley J, Selvamurugan N, Srinivasan N: Effects of cissus quadrangularis on the proliferation, differentiation and matrix mineralization of human osteoblast like SaOS-2 cells. J Cell Bioch 2011, 112:1035-1045.

34. Morris C, Thorpe J, Ambrosio L, Santin M: The soybean isoflavone genistein induces differentiation of MG63 human osteosarcoma osteoblasts. J Nutr 2006, 136:1166-1170.

35. Ikegami A, Inoue S, Hosoi T, Kaneki M, Mizuno Y, Akedo Y, Ouchi Y, Orimo H: Cell cycle-dependent expression of estrogen receptor and effect of estrogen on proliferation of synchronized human osteoblast-like osteosarcoma cells. Endocrinology 1994, 135:782-789.

36. Ducy P, Starbuck M, Priemel M, Shen J, Pinero G, Geoffroy V, Amling M, Karsenty G: A Cbfa1-dependent genetic pathway controls bone formation beyond embryonic development. Genes Dev 1999, 13:1025-1036.

37. Chen $\mathrm{CH}, \mathrm{Ho}$ ML, Chang JK, Hung SH, Wang GJ: Green tea catechin enhances osteogenesis in a bone marrow mesenchymal stem cell line. Osteoporos Int 2005, 16:2039-2045.

38. Qian G, Zhang X, Lu L, Wu X, Li S, Meng J: Regulation of Cbfa1 expression by total flavonoids of Herba epimedii. Endocr J 2006, 53:87-94.

doi:10.1186/s40199-014-0072-7

Cite this article as: Siddiqui and Arshad: Osteogenic potential of punica granatum through matrix mineralization, cell cycle progression and runx2 gene expression in primary rat osteoblasts. DARU Journal of Pharmaceutical Sciences 2014 22:72.

\section{Submit your next manuscript to BioMed Central and take full advantage of:}

- Convenient online submission

- Thorough peer review

- No space constraints or color figure charges

- Immediate publication on acceptance

- Inclusion in PubMed, CAS, Scopus and Google Scholar

- Research which is freely available for redistribution 